\title{
DEVELOPMENT AND ATRESIA OF FOLLICLES IN THE IMMATURE MOUSE
}

\author{
Hannah PETERS \\ The Finsen Laboratory, \\ The Finsen Institute, \\ Copenhagen (Denmark)
}

\section{INTRODUCTION}

The study of the development of the ovary during infancy and the immature period seems to be of unusual interest for several reasons. At maturity the ovary consists of follicles in all stages of development, small follicles, growing follicles, large follicles with and without follicle fluid. Furthermore, there are corpora lutea of different generations, peripheral and central stroma and a very well developed vascular and lymph system. It is an organ in which eggs mature and become competent, in which ovulation is prepared and achieved, an organ which manufactures hormones and is fully equipped to respond to hormones for which it serves as an end organ. At birth on the other hand, the ovary seems a much more uniform organ consisting mainly of small oocytes, stromal tissue and a rather primitive vascular system. In the short period of infancy between birth and the onset of maturity therefore a complex development in differentiation has to take place in this organ.

\section{THE DEVELOPMENT OF THE OVARY}

Right after birth the ovary consists mainly of small oocytes and stroma (fig. I). The oocytes lie close together in cell nests and many of the germ cells at this stage are still connected with intercellular bridges. The cell nests are surrounded by stroma cells. A central body of stroma cells is noted containing the end of rete tubules (BysKov and RASMUSSEN, I973). In ovaries of a 7 day old animal (fig. 2) the oocytes in the outer periphery are well separated. About $5 \mathrm{p}$. Ioo of the oocyte population have begun growth and are found in young follicles. The early follicles show one or even two rows of granulosa cells surrounding the egg. These are not seen in the new born, 
and the question arises, where the cells which become attached to the surface of the egg and then form the granulosa cells come from. Are they newly formed or did they arise from cells already in the organ at the time of birth?

Two sources have been identified. In part they originate from a pool of stroma cells already in the ovary, when the animal is born. This has been shown by marking stroma cells in the new born ovary with ${ }^{3} \mathrm{H} T \mathrm{TdR}$ and following their movements in consecutive autoradiographs in older animals (Peters and PEDERSEN, I967).

It has very recently been shown (BYSkov and LINTERN-MOORE, I973) that also cells from the rete tubuli contribute cells to the forming follicles. Byskov and LINTERNMOORE (I973) showed that in the early infant ovary a large number of oocytes share granulosa cells which are enclosed by a common basement membrane which is continuous with that of the rete ovarii. They suggested that rete cells which show the characteristics of amoeboid cells (BYskov and RASMUSSEN, I973) can move to the surface of the oocyte and become differentiated into granulosa cells. During the late infant period the connection in between follicles and between rete and follicles disappear, and the follicles with their granulosa cells become a closed system. Thus it is postulated that the cells which in the early neonatal period become attached to the surface of the small oocyte and begin to form the follicle cells come in part from the stroma and in part from rete tubuli.

At the end of the second week of life the ovary is still a solid organ filled with small and growing follicles (fig. 3). Concurrently with continued growth during the second week, other developments have taken place : most notably the formation of the theca layer and a differentiation of the vascular system with blood vessels surrounding the different follicles and branching into the outer cortex.

Before continuing with the description of the development of the ovary during the 3 rd and 4 th week, I would like to ask the question whether endogeneous gonadotropins (GTH) play a role in the early follicle development within the first two weeks of life. This has been tested by blocking endogenous gonadotropins after injecting an antigonadotropin daily during the first two weeks of life (ESHKOL, LUNENFELD and PLEERS, I970). A normal ovary of a two week old mouse (fig. 4) shows follicles with large regularly spaced follicle cells, a well developed theca layer and blood vessels. After daily injections of antigonadotropin for 2 weeks the ovary shows an abnormal follicle development with a poor granulosa cell layer, a failure of the theca layer to develop and a delayed development of the vascular system (fig. 4). Characteristically the oocyte growth seems undisturbed, as just as many growing oocytes were seen in the treated as in the untreated (EsHKoL, I970). Though the oocytes in the treated ovaries seem to be larger, they only appear so, as they are surrounded by ' a starved ' granulosa layer.

Adding GTH to the daily injection of antigonadotropin causes a reconstitution of a normal follicle envelop with a good granulosa cell layer, a normal theca and vascular system (fig. 5).

The changes seen after blocking endogenous GTH and their correction after addition of simultaneous GTH substitution suggest that also in early infancy endogenous GTH are necessary for normal follicle formation, $i$. e. development of the granulosa and theca layers, and the vascular system but apparently not for the stimulation of the oocyte to begin growth, the early attachment of cells to its surface, and the first stages of granulosa cell multiplication. 
During the third and fourth week of life the ovary takes on a very characteristic appearance which differs markedly from the ovary in early infancy (fig. 6). The cortex contains the small oocytes and although they are still by far the majority making up about $90 \mathrm{p}$. Ioo of the total oocyte population, they are easily overlooked, as they are dwarfed by the growing and large oocytes in developing follicles. These small follicles represent the pool of non-growing follicles from which all those are recruited that begin growth. Follicle development progressed so that there are simultaneously small, medium and large follicles seen. However, the follicles after reaching a certain size must degenerate, as hormonal interplay at that time allows follicle development only up to a certain stage. Many follicles in degeneration are therefore seen in the juvenile period.

\section{FOLLICLE GROWTH INITIATION}

In all ovaries throughout infancy one notices that follicle development is in progress and one can ask whether follicles actually start growth throughout infancy? It has recently become possible with cell dynamic studies to determine follicle growth and follicle kinetics in the immature ovary (PE'TERS and LEVY, I966; PEDERSEN, I969). PEDERSEN (I972) has been able to determine not only the number of follicles which begin to grow in the ovary per unit time at different ages, but also how long it takes a follicle from the time it begins growth until it reaches its final size.

Considering follicle growth three facts stand out : I) There is no period during infancy during which follicle growth is not initiated ; 2) Once a follicle starts growth it continues to do so until it either degenerates or is ovulated;3) The number of follicles which begin growth varies with age.

The number of follicles that begin growth is highest during the first week of life. About 40 follicles leave the pool of non-growing small follicles every 24 hours during the first week of life while only 20 do so during the fourth week (PEDERSEN, I969). Thus there is a marked reduction in the number of follicles that begin growth within the first four weeks of life. Also the speed with which follicles grow and develop varies with age. It is faster in the first week of life and decreases progressively until maturity is reached (PEDERSEN, 1972).

As it takes about I2-I4 days for the follicles that start growth on day 7 to become large follicles a maximum number of large follicles should be expected in the ovaries of 3 weeks old animals. This is actually the case. In all strains of mice examined so far an extraordinarily high number of large follicles is present in the ovary around day $2 \mathrm{r}$ (fig. 7). We can assume that this finds its explanation in the fact, that during the first 7 days of life a very large number of follicles left the pool of small resting follicles and started to grow, these become large follicles I4 days later and make up the unusually high number present in 2I day old animals. As the hormonal interplay does not yet support their further growth and ovulation, many of these degenerate. I shall a little later come back to this unusual situation of massive degeneration of follicles in the 3 week old animal.

As follicles start growth at all times during infancy the question arises what is known about follicle growth initiation and what mechanisms and substances influence 
the number of follicles that leave the pool of small non-growing follicles? Usually when we think of follicle growth, we mean the large follicles and the recruitment of a certain group of large follicles which come to ovulation. We would like to extend this concept and concern ourselves with the growth initiation and try to define what influences the beginning of follicle development. Is it a stimulus that acts on the pool, stimulating some to leave it, or might it be an inhibitor, that prevents most cells in the pool from leaving and allows only some to escape?

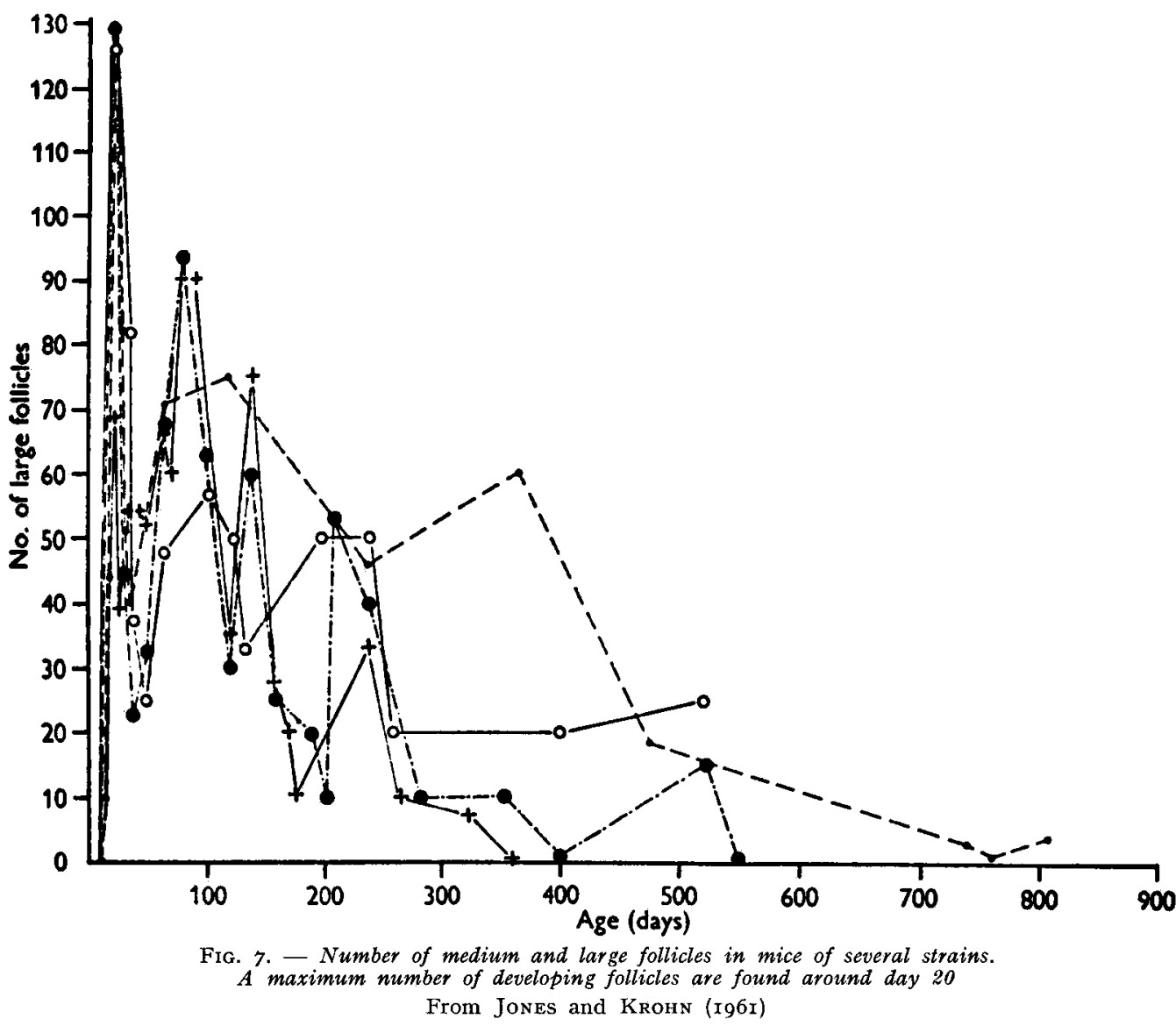

FIG. 7. Nombre de follicules moyens et grands chez des Souris de plusieurs lignées. On observe le plus grand nombre de follicules en developpement vers 20 jours.

\section{THE ROLE OF GONADOTROPIN}

\section{IN FOLIICLE GROWTH INITIATION}

The experiments reported earlier in which endogeneous GTH were blocked for the first two weeks of life seemed to suggest, that despite of the block oocyte growth and the beginning formation of follicles continued. It was therefore thought of 
interest to test, whether growth initiation could be enhanced by exogenous GTH stimulation in the early infant period. This was tested by injecting one IU of PMS three times a day for 4 days between the ages of day 3 and 6 . The animals were sacrificed and the number of follicles that had started growth was estimated by counting the number of follicles with more than 20 granulosa cells on the largest cross-section. These represent the beginning stages of follicle growth, they are those, which have left the pool of resting, small follicles. As controls served litter mates which had received subcutaneous injections of salt solution on the same time schedule. The results showed (table I), that the number of follicles that had started growth was the same after GTH stimulation and salt injection. This suggests, that exogenous GTH does not stimulate an increase in the number of follicles that start growth.

\section{TABLE I}

Number of follicles that started growth in 6 day old mice after daily injections of PMS and in control animals

Nombre de follicules qui co:nmencent à se développer

chez des Souris de 6 jours normales ou recevant chaque jour une injection de PMS

NUMBER OF FOLLICLES WITH MORE THAN

20 CELLS ON LARGEST CROSS SECTION

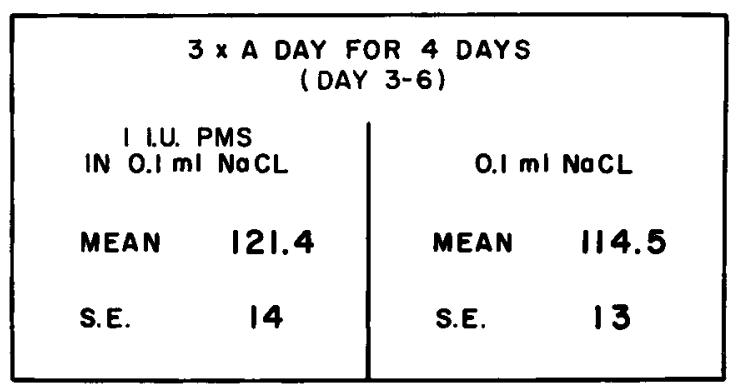

We therefore conclude that neither blocking of endogenous GTH during the first two weeks, nor the exogenous addition of GTH in the neonatal period alters the number of follicles that leave the pool.

\section{INTRAOVARIAN INFLUENCES \\ ON FOLLICLE, GROWTH INITIATION}

If extraovarian regulation of the start of follicle growth seems unlikely we would like to focus our attention on intraovarian events which could influence the number of follicles leaving the pool of resting, small follicles. Two events seem noteworthy.

I. With advancing age the total number of follicles and in particular the nongrowing follicle pool is reduced. It can be shown that the size of the pool in itself 
has an influence on growth initiation (KRARUP, PEDERSEN and FABER, I969). As the number of small oocytes decreases, the number of follicles that start growth decreases also (fig. 8). It is immaterial whether this reduction is affected by an increase in age, or whether the pool is artificially reduced at an early age, $f . i$. by radiation, by feeding of a carcinogen or by an injection of testosterone propionate during the neonatal period.

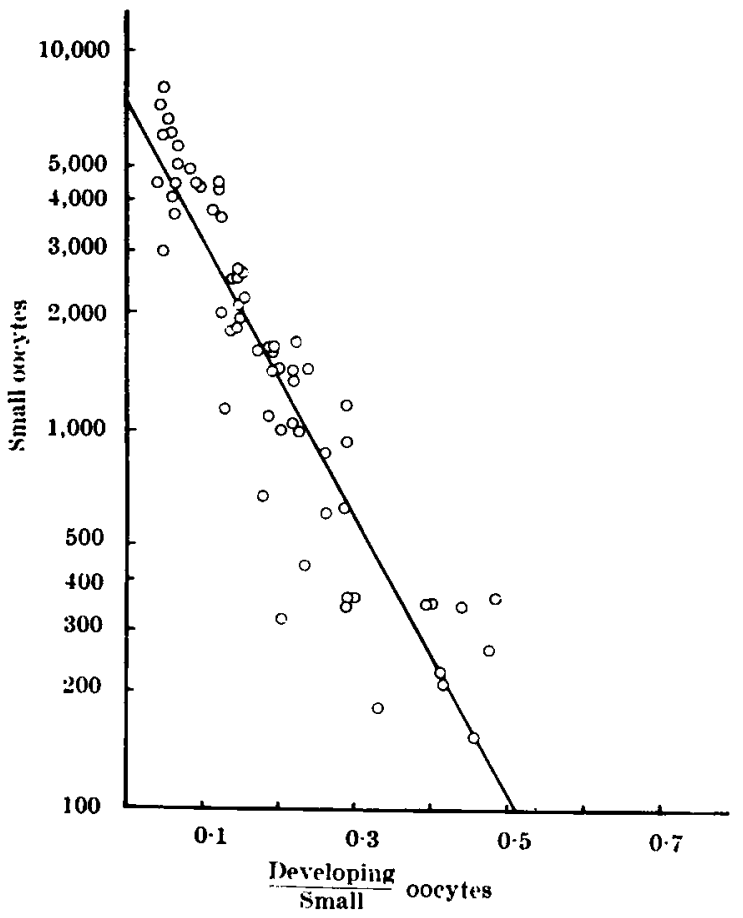

FIG. 8. - Relation of developing/small oocytes to number of small oocytes From Krarup, Pedersen and Faber ( 1969 )

FIG. 8 - Relation entre le nombre de petits ovocytes et le rapport ovocytes en développement/petits ovocytes

That reduction of the pool at an early age actually alters the number of follicles that begin growth can be tested after testosterone propionate injection on day five, which in mice reduces the pool of small oocytes by $50 \mathrm{p}$. roo within 2 days. It was found that the number of follicles which start growth after that period is smaller than in a normal animal. While 40 follicles begin growth per day in a normal 7 day old mouse only 24 do so at the same age after TP treatment (PETERS, SÖRENSEN, Byskov, Pedersen and KRARUP, I970).

Apparently it is not the age of the mouse which determines how many follicles start to grow, but the number of small oocytes which remain in the pool after the treatment. Thus it seems, that the size of the pool of small, resting follicles in itself has an influence on the number leaving the pool.

2. But this is not enough to explain the marked change in the number of follicles which start to grow at different times in infancy. The very high starting rate during the immediate neonatal period which falls to $50 \mathrm{p}$. Ioo three weeks later suggests, 
that in the intervening time a factor might begin to act, which impedes the growth initiation. I would like to come back to the finding that around day $2 I$ in all strains of mice, the highest number of large follicles is present in the ovary, and a considerable degeneration of follicles occurs around that time. This raises the question whether the disintegrating cells in degenerating follicles might free a substance which influences growth initiation. It was reasoned, that if the degenerating granulosa cells liberate such a substance into the follicle fluid which slows down growth initiation, it should be possible experimentally to reduce the number of follicles that begin growth in the neonatal period by injecting follicle fluid from large follicles into infant mice. This was done (PETERs, Byskov and FABER, I973). Follicle fluid was collected from large follicles of cow ovaries and injected subcutaneously three times a day between day 3 and day 6 into infant mice. On day 6 the number of follicles that had started growth were determined and compared with the number found in litter mate controls. The results showed that a significantly smaller number of follicles started growth in mice injected with follicle fluid than in the controls. In animals that had received follicle fluid $\mathrm{I} 24$ follicles had started growth on day 6 , while I93 had left the non-growing follicle pool in the controls. Thus one third of the number that usually start growth at that age had been prevented from doing so. This infers that follicle fluid from large follicles contains a substance or substances able to depress growth initiation.

This correlates well with the change that occurs during infancy in the number of follicles that start growth. During the first week of life no large follicles are as yet in the ovary and growth initiation is high. During the following weeks a progressively larger number of large follicles form and degenerate which, progressively impede growth initiation. Work is now in progress to characterize the susbtances contained in fluid from large follicles which influence growth initiation.

The problem of follicle growth initiation is far from being solved but we are suggesting that at least two intraovatian factors have an influence on the number of follicles that leave the pool of non-growing, small follicles: One is the size of the pool itself. With the reduction of the size of the pool the number leaving it becomes smaller. A second one concerns the degenaration of large follicles which seem to free a substance which restrains growth initiation.

\section{ACKNOWLEDGEMENTS}

I would like to thank the authors and holders of copyright for permission to reproduce figures used in this paper: The Journal of Endocrinslogy (fig. 7), Nature (fig. 8).

\section{RÉSUMÉ}

\section{DÉVELOPPEMENT ET ATRÉSIE DES FOLLICULES CHEZ LA SOURIS IMMATURE} plexe.

L'initiation de la croissance folliculaire dans l'ovaire est un problème important mais com-

Dans un ovaire de souris de 7 jours s'édifient des follicules constitués par un ovocyte en touré 
de cellules dont l'origine est double : le pool de cellules stromales présentes dans l'ovaire à la naissance, mais aussi des cellules du rete tubuli.

Les changements observés après blocage de l'action des gonadotrophines endogènes par des antigonadotrophines et après addition de gonadotrophines de substitution suggèrent que ces hormones sont :

- nécessaires au développement des couches de la granulosa et de la thèque ;

- ne sont pas nécessaires à la stimulation du début de la croissance de l'ovocyte, à la mise en place des cellules à sa surface et à leurs premières multiplications. natale.

Cette initiation de la croissance folliculaire est très importante dans la $2^{\mathrm{e}}$ semaine post-

D'une manière générale l'initiation de la croissance folliculaire dépendrait d'au moins deux facteurs intraovariens : l'importance du pool de petits follicules au repos, la libération par les gros follicules de substances qui freineraient l'initiation de la croissance.

\section{REFERENCES}

Byskov A. G., Lintern-Moore S., I973. Follicle formation in the immature mouse ovary: the the role of the rete ovarii (in preparation).

Byskov A. G., Rasmussen G., I973. Ultrastructural studies of the developing follicles. Proceedings of Symposium Development and Maturation of the Ovary and its Functions. Excerpta Medica Int. Congress Series. No 267.

EsнкоL A., 197o. The role of gonadotropic hormones in the development of the infantile mouse ovary. Thesis Bar Ilan University, Tel Aviv.

Eshrol A., Lunenfeld B., Peters H., 1970. Ovarian development in infant mice. Dependence on gonadotropic hormone. In : Gonadotrophins and Ovarian Development. E. and S. Livingstone, Edinburgh and London.

Jones E. C., KroHN P. L., r96r. The relationships between age and numbers of oocytes and fertility in virgin and multiparous mice. J. Endocr., 21, 469-495.

Krarup T., Pedersen T., Faber M., I969. Regulation of oocyte growth in the mouse ovary. Nature, 224, I87-I88.

Pedersen T., 1969. Follicle growth in the immature mouse ovary. Acta Endocr., 62, II7-r32.

Pedersen T., I972. Follicle growth in the mouse ovary. In : Oogenesis. Ed. J.-D. Biggers and A. W. Schuetz, University Park Press, Baltimore and Butterworth, London, p. 36I-376.

Peters H., Byskov A. G., FAber M., 1973. Intraovarian regulation of follicle growth in the immature mouse. Proceeding of Symposium Development and Maturation of the Ovary andits Functions. Excerpta Medica Int. Congress Series. No 267.

Peters H., Levy E., I966. Cell dynamics of the ovarian cycle. J. Reprod. Fertil., 11, 227-236.

Peters H., Pedersen T., 1967. Origin of follicle cells in the infant ovary. Fertil. Steril., 18, 309-313.

Peters H., Sörensen I. N., Byskov A. G., Pedersen T., Krarup T., I97o. The development of the mouse ovary after testosterone propionate injection on day 5 . In : Gonadotrophins and Ovarian Development. E. and S. Livingstone, Edinburgh and London., p. 351-36r. 
PLATES 


\section{PLATE I}

FIG. I

The ovary at birth consists mainly of small oocytes and stroma cells $(\times 280)$.

FIG. 2

Ovary of a 7 day old mouse ( $X$ 120).

FIG. 3

Follicles in a normal I4 day old mouse with well developed granulosa and theca layer $(x 475)$.

\section{PLANCHE I}

FIG. I

Ovaire à la naissance composé surtout de petits ovocytes et des cellules du stroma.

FIG. 2

Ovaire de souris de 7 jours.

FIG. 3

Follicules chez une souris de 14 jours avec la granulosa et les thèques bien développées. 


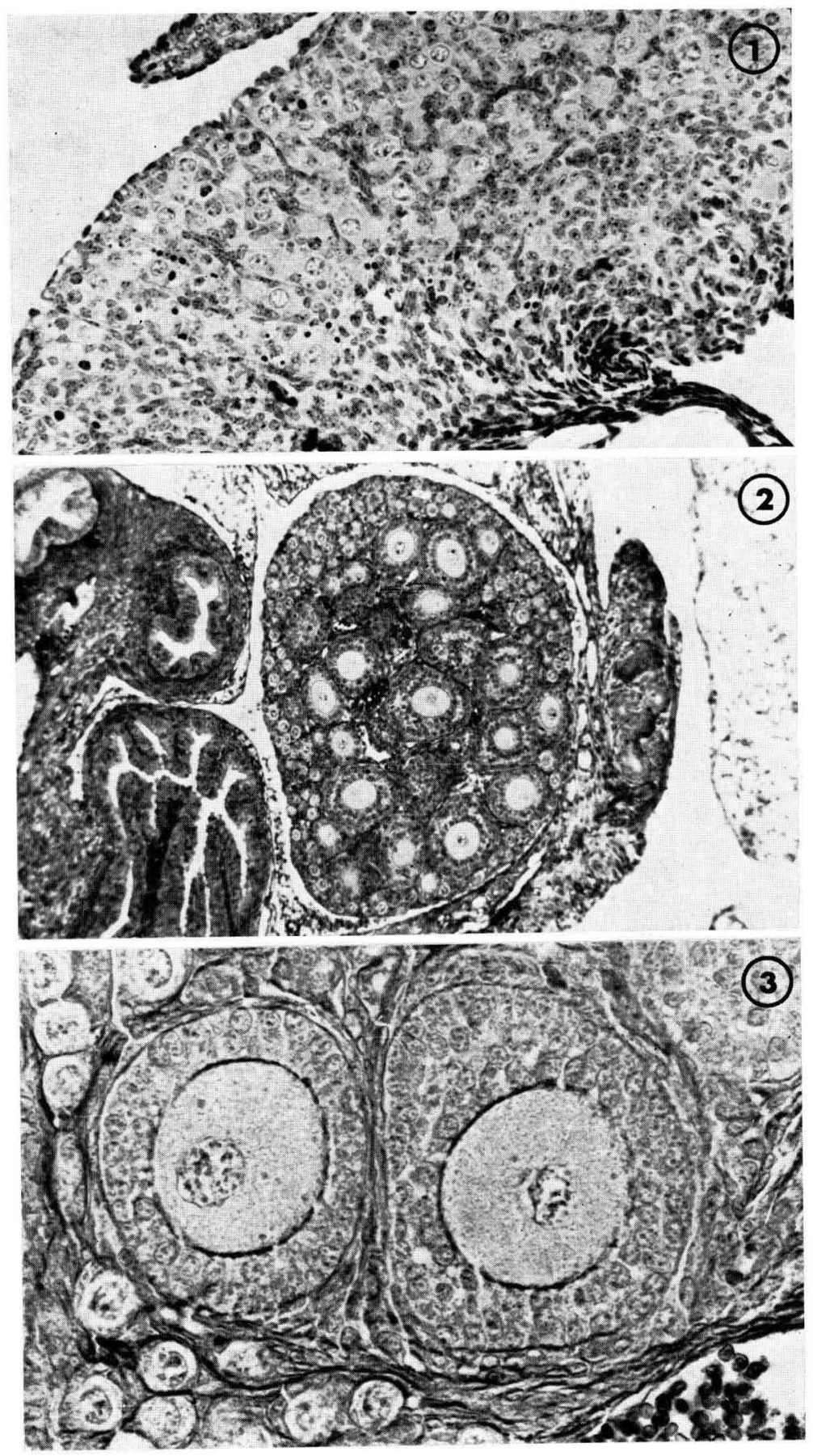




\section{PLATE II}

FIG. 4

Follicles in a 14 day old mouse injected daily with antigonadotropin. Poorly developed granulosa layer and "empty " theca space. $\times 475$.

FIG. 5

Follicles in a 14 day old mouse injected daily with antigonadotropin plus gonadotropins. Granulosa and theca layers are restored. $\times 475$.

FIG. 6

Ovary of a 1 month old mouse. $\times 45$.

\section{PLANCHE II}

FIG. 4

Follicules chez une souris de 14 jours injectée chaque jour avec un sérum antigonadotrope. La granulosa est peu développée et les thèques absentes.

FIG. 5

Follicules chez une souris de 14 jours recevant chaque jour un sérum antigonadotrope et des gonadotropines. La granulosa et les thèques sont restaurées.

FIG. 6

Ovaire d'une souris de 1 mois. 
PLATE II
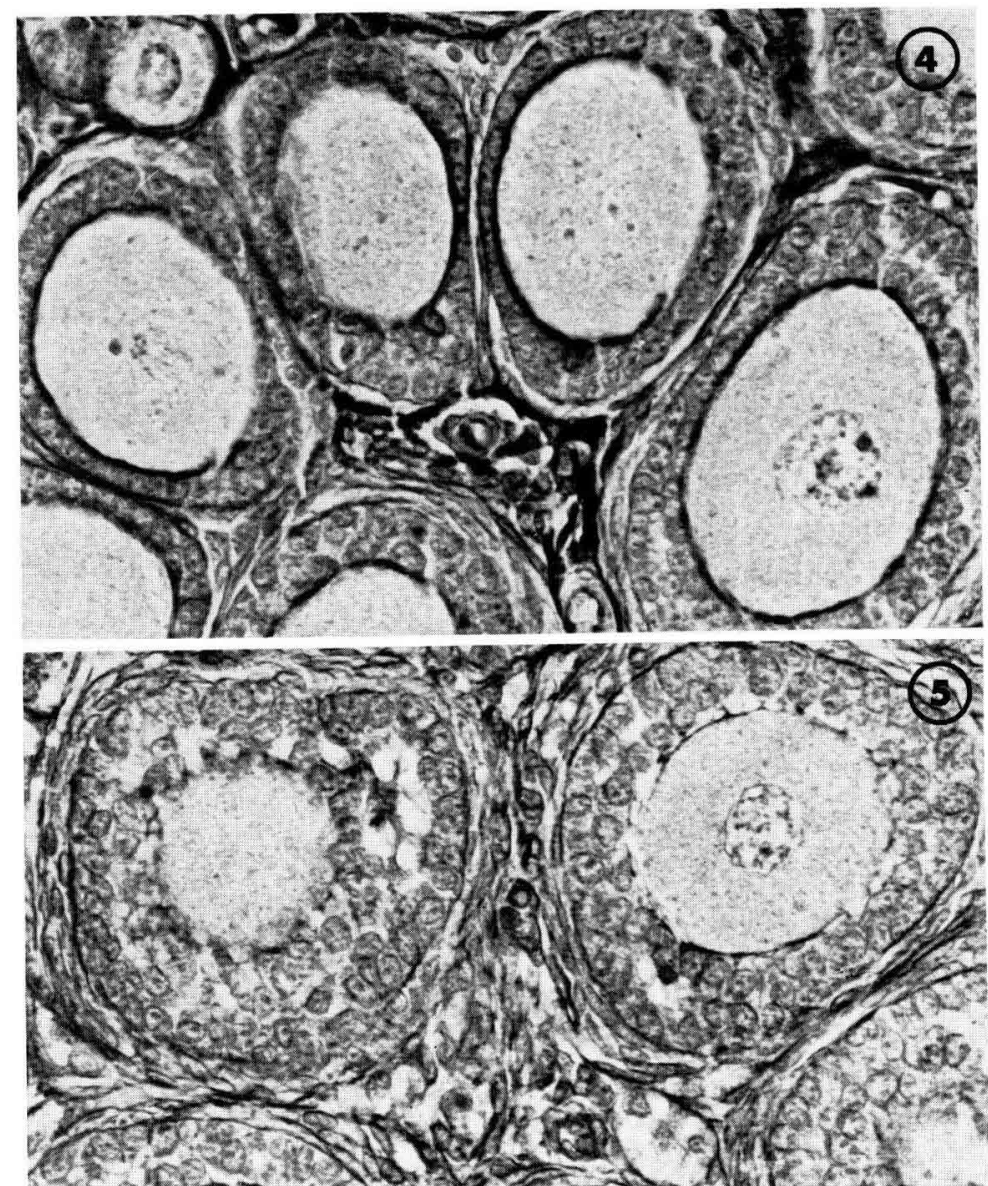

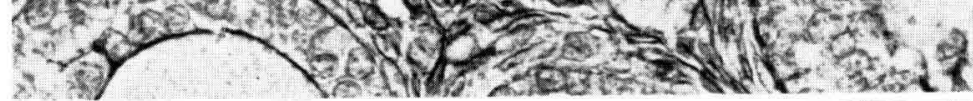

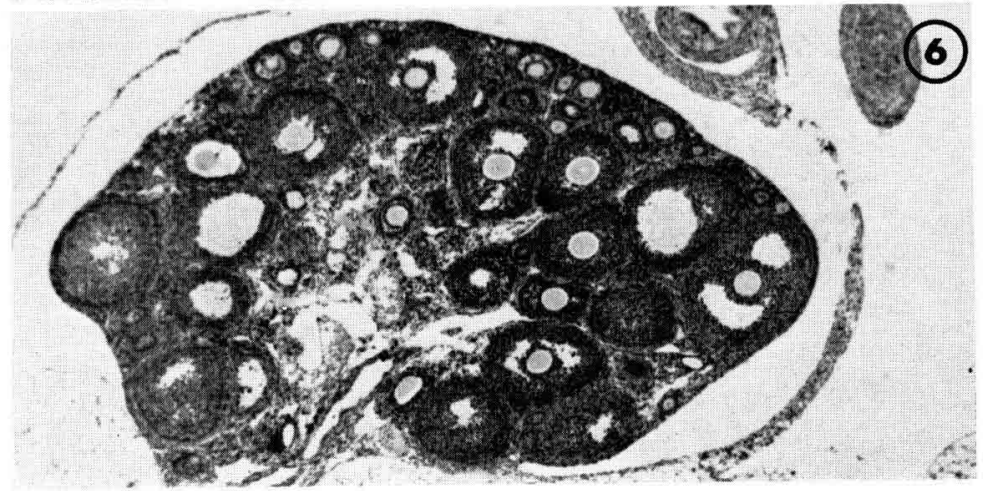

